\title{
The Research on the Impact of Government Electronic Information Services Quality on Citizen Participation
}

\author{
Peiyun Jiang ${ }^{1, *}$ \\ ${ }^{1}$ School of Public Affairs and Administration, University of Electronic Science and Technology of China, Chengdu, \\ Sichuan 611731, China \\ *Corresponding author. Email: jiangpy0425@126.com
}

\begin{abstract}
In the age of Internet, citizens mostly access the information of government policies and activities through the Internet, and the quality of government information has a profound impact on public participation. In this paper, 338 citizens of Chengdu City who get access to government information online are taken as research samples to analyze the impact of the quality of e-government information got on public participation. It is found that the process quality, result quality, remedial quality and environmental quality of online access to information have significant positive effects on public participation. Under the background of vigorously promoting Internet + government services, the information publication, as the primary function of electronic governance, is conducive to improve public participation by optimizing the quality of public online accessing government information.
\end{abstract}

Keywords: e-government, quality of information, citizen participation

\section{INTRODUCTION}

The rapid development of information technology brings new opportunities as well as challenges to government decision-making and management. As the primary function of electronic governance, electronic information publication can not only effectively bridge the information gap between the government and the public, so as to improve the citizens' right to know, but also expand the channels of citizens' participation in politics and increase the opportunities for citizens to discuss politics. Nowadays, citizens mainly obtain the policies and event information of related government departments through network channel. Based on this, this paper focuses on the impact of e-government quality of information service on citizen participation. The core issue of this paper is to explore which dimensions of e-government quality of information service may have an impact on citizen participation, and what are the differences of the effect on each dimension.

\section{BASIC CONCEPTS AND LITERATURE REVIEW}

\subsection{Government Electronic Information Services Quality}

Most scholars agree that service quality is the difference value between the user's expected service and perceived service, and on this basis, they put forward many related models for measuring different service quality. The quality of e-government information service refers to the user's perceived performance and actual performance level of government services in the process of accessing to the website, APP, WeChat and microblog of various government departments to obtain related policies and event information of government by internet technology, which can be regarded as the citizens' overall evaluation on the government's e-government information services. In this paper, the quality of electronic public information service perceived by the public is divided into four dimensions which include process quality, result quality, environmental quality and remedial quality. These four dimensions are partly with the reference of the dimensions of the functional quality (service result quality) and technical quality (service process quality) proposed by Gronroos[1], and the interactive quality, environmental quality and result quality proposed Brady \& Cronin[2], and partly co-opted online service quality scale E-SQUAL and the content of E-RecS-QUAL proposed by Parasuraman[3].Specifically, the process quality is used to measure the simplicity and convenience of obtaining Egovernment public information; the result quality is used to measure the concrete value achievements of obtaining E-government public information; the environmental quality is used to measure the technical support, privacy protection and interface design of the system; and the remedial quality is used to measure the responsiveness of online staff to the public seeking for relevant assistance.

\subsection{Citizen participation}

Arnstein (1969) first put forward the concept of citizen participation, he regarded it as the process of redistribution of power, during which the citizens express their preferences, needs and suggestions to provide decisionmaking reference for the government.[4] According to the theory of good governance, the government should not be 
H9: The higher the quality perception of e-government information service process, the higher the degree of citizen participation

H10: The higher the quality perception of e-government information service results, the higher the degree of citizen participation

H11: The higher the perception of remedial quality of egovernment information service, the higher the degree of citizen participation

H12: The higher the perception of environmental quality of e-government information service environment, the higher the degree of citizen participation

\section{RESEARCH DESIGN}

\subsection{Research sample}

In this paper, online questionnaire survey is employed to collect sample data. And the respondents are ordinary citizens who have used websites, APP, WeChat and Microblog of government to obtain related government information. They are asked to evaluate the quality of egovernment information acquisition and the degree of citizen participation according to their own experience of obtaining related government information. A total of 363 questionnaires were sent up online, and after eliminating the invalid questionnaires, the number of valid questionnaires is 338 , with an effective rate up to $93 \%$. Among them, the specific distribution of survey samples is as shown in the figure:

Table 1: Composition of sample

\begin{tabular}{|c|c|c|}
\hline Variables & Numbers & Ratio \\
\hline \multicolumn{3}{|l|}{ 1.Gender } \\
\hline Male & 178 & $52.66 \%$ \\
\hline Female & 160 & $47.33 \%$ \\
\hline \multicolumn{3}{|l|}{ 2.Politic status } \\
\hline Party member & 70 & $20.71 \%$ \\
\hline Non-party member & 268 & $79.39 \%$ \\
\hline \multicolumn{3}{|l|}{ 3.Age } \\
\hline $18-24$ & 38 & $11.24 \%$ \\
\hline 24-29 & 114 & $33.73 \%$ \\
\hline $30-39$ & 87 & $25.74 \%$ \\
\hline $40-49$ & 67 & $19.82 \%$ \\
\hline 50 and above & 32 & $9.47 \%$ \\
\hline \multicolumn{3}{|l|}{ 4.Education status } \\
\hline $\begin{array}{c}\text { Junior high } \\
\text { school and below }\end{array}$ & 11 & $3.25 \%$ \\
\hline High school & 76 & $22.49 \%$ \\
\hline $\begin{array}{c}\text { University } \\
\text { /Technical college }\end{array}$ & 203 & $60.06 \%$ \\
\hline $\begin{array}{l}\text { Postgraduate } \\
\text { and above }\end{array}$ & 48 & $14.20 \%$ \\
\hline \multicolumn{3}{|l|}{ 5.Monthly income } \\
\hline 3000 and below & 92 & $27.22 \%$ \\
\hline $3001-5000$ & 74 & $21.89 \%$ \\
\hline
\end{tabular}




\begin{tabular}{|c|l|}
\hline & $\begin{array}{l}\text { search, which can guide me to find } \\
\text { information in need. }\end{array}$ \\
\hline \multirow{5}{*}{$\begin{array}{l}\text { Result } \\
\text { updates related information in time } \\
\text { to help me understand the latest } \\
\text { developments of the government } \\
\text { 2. The information provided by } \\
\text { online government platform is rich } \\
\text { and comprehensive, which can } \\
\text { basically meet my needs. } \\
\text { 3. Online government platform } \\
\text { provides authentic and accurate } \\
\text { information which is worthy of my } \\
\text { trust. } \\
\text { 4. The information provided by } \\
\text { online government platform is clear } \\
\text { and easy to understand. }\end{array}$} \\
\hline Remedial \\
quality & $\begin{array}{l}\text { 1. In case of failed information } \\
\text { seeking, contact personnel online for } \\
\text { relevant guidance is available. } \\
\text { 2. Seeking professional explanations } \\
\text { through online consultation is } \\
\text { available when feel difficult of } \\
\text { information interpretation. } \\
\text { 3. The online service staff is sincere, } \\
\text { friendly and professional. }\end{array}$ \\
\hline $\begin{array}{l}\text { 1. Online government platform runs } \\
\text { stably, loads fast, and resources are } \\
\text { accessible. } \\
\text { 2. Online government platform can } \\
\text { resist hacker attack and ensure the } \\
\text { information security of users. } \\
\text { 3.The interface design of online } \\
\text { government platform is aesthetic and } \\
\text { simple, and the layout reasonable, } \\
\text { conforming to my usage. }\end{array}$ \\
\hline
\end{tabular}

Table 2: Main variables and their measurement items

\begin{tabular}{|c|l|}
\hline Variables & \multicolumn{1}{|c|}{ items } \\
\hline \multirow{5}{*}{$\begin{array}{c}\text { Citizen } \\
\text { participation } \\
\text { policy-making of relevant } \\
\text { departments of the municipal } \\
\text { government. } \\
\text { 2. I believe that the municipal } \\
\text { government concerns about the ideas } \\
\text { and needs of ordinary people } \\
\text { 3. I have a clear understanding of the } \\
\text { work and functions of relevant } \\
\text { departments of the municipal } \\
\text { government } \\
\text { 4. I would like to participate in the } \\
\text { investigation and voting of relevant } \\
\text { departments of the municipal } \\
\text { government. }\end{array}$} \\
\hline $\begin{array}{c}\text { 1. The way I get demand } \\
\text { information through the network is } \\
\text { simple, fast and easy to operate. } \\
\text { 2. Online government platform } \\
\text { provides functions of navigation and }\end{array}$ \\
\hline
\end{tabular}

\subsection{Testing of reliability and validity}

To test the reliability of the variables using coefficient $\alpha$, the larger the coefficient $\alpha$ is, the higher the reliability of the consistency of the scale is. Generally, the reliability of the scale is above 0.7 , which indicates that the reliability is about good. The reliability coefficients of each variable are $0.856,0.849,0.881$ and 0.813 respectively, and of the overall dimension is 0.831 . while the dimension of citizen participation is 0.883 , which accounts for the high reliability of this questionnaire. After inspection, four shared elements were extracted by the extraction method of principal component analysis applied by the e-government information scale. And the eigenvalues before the four shared elements' spin axis were 4.332, 2.512, 1.204 and 1.142 respectively. While the eigenvalues after the spin axis of direct oblique method were 2.775, 2.423, 2.198 and 1.795 respectively. The four elements can extract $76 \%$ of the information, indicating that the construction validity of the extracted four elements is good and suitable for factor analysis. 


\begin{tabular}{|c|c|c|c|}
\hline $\begin{array}{c}\text { Environment } \\
\text { al quality }\end{array}$ & & & $\begin{array}{r}0.138 * * \\
(2.473) \\
\end{array}$ \\
\hline $\begin{array}{c}\text { Political } \\
\text { interest }\end{array}$ & & $\begin{array}{c}0.153 * * * \\
(2.811)\end{array}$ & $\begin{array}{c}0.119 * * \\
(2.423)\end{array}$ \\
\hline $\begin{array}{c}\text { Time } \\
\text { of online }\end{array}$ & & $\begin{array}{c}0.065 \\
(1.194) \\
\end{array}$ & $\begin{array}{c}0.005 \\
(0.101) \\
\end{array}$ \\
\hline Gender & $\begin{array}{l}-0.124 * * \\
(-2.331) \\
\end{array}$ & $\begin{array}{l}-0.117 * * \\
(-2.221) \\
\end{array}$ & $\begin{array}{c}-0.057 \\
(-1.193) \\
\end{array}$ \\
\hline $\begin{array}{c}\text { Political } \\
\text { status }\end{array}$ & $\begin{array}{c}-0.136 * * \\
(-2.565) \\
\end{array}$ & $\begin{array}{l}-0.104 * \\
(-1.943) \\
\end{array}$ & $\begin{array}{r}-0.122 * * \\
(-2.540) \\
\end{array}$ \\
\hline Age & $\begin{array}{l}0.095 * \\
(1.764) \\
\end{array}$ & $\begin{array}{l}0.095^{*} \\
(1.757) \\
\end{array}$ & $\begin{array}{c}0.044 \\
(0.911) \\
\end{array}$ \\
\hline $\begin{array}{c}\text { Educational } \\
\text { status }\end{array}$ & $\begin{array}{c}0.183 * * * \\
(3.462)\end{array}$ & $\begin{array}{c}0.162 * * * \\
(3.068)\end{array}$ & $\begin{array}{l}0.082^{*} \\
(1.717)\end{array}$ \\
\hline $\begin{array}{c}\text { Monthly } \\
\text { income }\end{array}$ & $\begin{array}{c}-0.037 \\
(-0.686) \\
\end{array}$ & $\begin{array}{c}-0.036 \\
(-0.665) \\
\end{array}$ & $\begin{array}{l}-0.021 \\
(0.446) \\
\end{array}$ \\
\hline $\begin{array}{c}\text { Constant } \\
\text { term }\end{array}$ & $(8.355) * * *$ & $(6.075) * * *$ & $\begin{array}{c}(2.536) \\
* * \\
\end{array}$ \\
\hline Adjust $\mathrm{R}^{2}$ & 0.071 & 0.089 & 0.289 \\
\hline $\begin{array}{c}\text { Variation of } \\
\mathrm{R}^{2} \\
\end{array}$ & & 0.023 & 0.204 \\
\hline F value & 6.122 & 5.683 & 13.425 \\
\hline
\end{tabular}

\section{CONCLUSION, INSPIRATION AND PROSPECT}

In model 3, taking citizen participation as the dependent variable, and on the foundation of controlling basic variables of time of online, degree of political interest and of population characteristics, to introduce the independent variables of public perception of process quality, result quality, remedial quality and environmental quality of egovernment information service. The regression results show that process quality, result quality, remedial quality and environmental quality are related to citizen participation in a significant positive correlation, and its explanatory power is $28.9 \%$. Among which, after the introduction of independent variables, only political interest, political status and education status are still with some significance. Specifically, among the four independent variables, remedial quality, result quality, process quality and environmental quality, the impact of them on citizen participation weakens successfully, which shows that citizens pay more attention to the actual value of information acquisition and interaction with online personnel than the process of it.

Table 3 Regression Model

\begin{tabular}{|c|c|c|c|}
\hline $\begin{array}{c}\text { Mode } \\
\text { Variables } \\
\text { Illustration }\end{array}$ & $\begin{array}{c}\text { Model1 } \\
\text { Citizen } \\
\text { participation }\end{array}$ & $\begin{array}{c}\text { Model2 } \\
\text { Citizen } \\
\text { participation }\end{array}$ & $\begin{array}{c}\text { Model3 } \\
\text { Citizen } \\
\text { participation }\end{array}$ \\
\hline Process & & & $0.138^{* *}$ \\
quality & & & $(2.533)$ \\
\hline Result & & & $0.196^{* * *}$ \\
quality & & & $(4.036)$ \\
\hline Remedial & & & $0.213^{* * *}$ \\
quality & & & $(3.702)$ \\
\hline
\end{tabular}

\subsection{Conclusion exploring}

Based on the existing research results at home and abroad, this paper randomly selected data of online access to government information of 338 citizens in Chengdu through the way of online questionnaire, and specifically analysed the impact of the quality of citizens' e-government information acquisition on citizen participation. And The research results of it show that the citizens' quality perception of online access to information are with a significant positive prediction on citizen participation. Among them, the remedial quality and the result quality have a relatively strong impact on citizen participation, which indicates that the actual value of information acquisition and the real-time response are more associated with citizens' willingness and behavior to participate. Specifically, remedial quality refers to the online real-time service available to citizens when they are blocked in the process of information access. It can help citizens obtain the information in need, solve their doubts, so as to make up for the shortcomings and omissions of the information services in a timely manner. This indicates that providing guidance to citizens to solve problems in a timely manner can help citizens improve their acknowledge of and understanding of the government, which is also the support of the government can with ability to guarantee the quality of information services. While the result quality refers to the actual value of the information that citizens ultimately obtain, and the quality of it reflects the government's capacity for 
management and willingness to act. It is an important window from which citizens come to understand the operation of government institutions and it is also the necessary premise for them to participate in the management of government affairs.

\subsection{Experimental inspiration}

In the context of the Internet era, with the help of the electronic platform, the government departments have expanded the channels of citizen participation to a certain extent and increased the opportunities for citizen to participate. The study results of this paper reveal that citizens' quality perception of e-government information is with a positive impact on citizen participation, which brings some policy implications for improving citizens' participation. Citizens participate in the governance process of government departments actively, which can make citizens legally and reasonably resort to their interest demand, help to form rational expectations, and further promote the democratization and scientization of government decision-making. The quality of e-government services perceived by the public defines a clear direction for improving citizen participation. Acknowledge is the premise of participation. The higher the citizens' perception quality of the e-government information services is, the more comprehensive and in-depth their acknowledgments of government departments are, so that they have the ability to directly participate in public affairs and be more exposed to related activities of government departments. Therefore, the government must pay much attention to the transparency and openness of government information, actively establish an e-government service platform of intelligent government which is centered on citizens, expand the development, utilization and management of government information resources, and guarantee the information publicity system. In addition, the government should adhere to the principle of openness, taking it as a normalcy while the non-openness as the exception, and of fairness, legality and convenience for the people and strive to provide the public with high-quality information service experience, guarantee the people's right to know and of supervision, so as to promote the public to know more about the operation of the government, then improve the willingness and behavior of citizens to participate in the administration and discussion of state affairs.

\subsection{Study prospect}

There are still some deficiencies in this study of this paper, which need further improvement. First of all, the samples in this study are confined within Chengdu City, which is with a strong regional character. It is needed to expand the samples throughout the country so as to make the conclusion more universal and scientific. Secondly, the variable operation of this paper is relatively rough. There can be a further refinement of the citizen participation, for instance, it can be further divided according to the mode and motivation of citizen participation to explore the impact of different forms of participation.

\section{REFERENCES}

[1] Grönroos, Christian."A Service Quality Model and Its Marketing Implications. " European Journal of Marketing, vol.18,no.4,1984,pp.36-44.

[2] Brady, Michael K., and J. Joseph Cronin. “Some New Thoughts on Conceptualizing Perceived Service Quality: A Hierarchical Approach." Journal of Marketing, vol.65,no.3,2001,pp.34-49.

[3] Parasuraman, A,et al."E-S-QUAL:A Multiple-Item Scale for Assessing Electronic Service Quality.”Journal of Service Research: JSR,2005,pp.213-233.

[4] Arnstein,Sherry R.“A Ladder Of Citizen Participation."Journal of the American Institute of Planners, vol.35, no.4,1969, pp.216-224.

[5] David H.Rosenbloom, Robert S. Kravchuk,Richard M. Clerkin. Public Administration: understanding Management, politics seven edition,McGraw-Hill higher education press, 2008 .

[6] Soonhee Kim, Jooho Lee.E-Participation, Transparency, and Trust in Local Government[J].Public Administration Review.2012 (12):830. 